Trinity University

Digital Commons@ Trinity

English Faculty Research

English Department

2012

\title{
My Kingdom: Sentimentalism and the Refinement of Hymnody
}

Claudia Stokes

Trinity University, cstokes@trinity.edu

Follow this and additional works at: https://digitalcommons.trinity.edu/eng_faculty

Part of the English Language and Literature Commons

\section{Repository Citation}

Stokes, C. (2012). My kingdom: Sentimentalism and the refinement of hymnody. ESQ: A Journal of the American Renaissance, 58(3), 294-337. doi: 10.1353/esq.2013.0003

This Article is brought to you for free and open access by the English Department at Digital Commons @ Trinity. It has been accepted for inclusion in English Faculty Research by an authorized administrator of Digital Commons@ Trinity. For more information, please contact jcostanz@trinity.edu. 


\section{My Kingdom: Sentimentalism and the Refinement of Hymnody}

GLAUDIA STOKES

Few features of mid-nineteenth-century American women's literature seem as foreign and outdated today as the omnipresence of hymns. In countless literary works, hymns are quoted, sung, discussed, and contemplated. Hymns in these texts are rivaled in influence only by the Bible and are potent catalysts of religious experience, sparking conversion in the unbeliever and offering reassurance to the faithful during times of trouble. In the literary world of the American mid-century, the singing of a hymn can bring tears to the eyes of even the most hardened unbeliever. Such scenes pervade fiction of the period. During Ellen Montgomery's sorrowful trip to live with her Aunt Fortune in Susan Warner's The Wide, Wide World (I850), a kindly stranger ministers to her by inviting her to read a hymn and then gives her his hymnal. In Uncle Tom's Cabin (I85I-52), Harriet Beecher Stowe excerpts the hymns favored by slaves and depicts Tom as such an avid singer of hymns that he is revived on his death-bed only by the recitation of a few lines from a hymn by Isaac Watts. In Louisa May Alcott's Little Women (I868), the March sisters sing their "father's favorite hymn" after learning of his grave illness, and, at the height of her own illness, Beth March plays and sings John Bunyan's hymn "He That is Down Need Fear No Fall." 
For modern readers, these scenes of popular hymnody may seem quaintly old-fashioned and evoke a religious life steeped in homely, wholesome piety. However, to read these novels in the complex history of hymnody in the English-speaking world is to see this fond, warm portrayal of hymnody as a deft literary construction so convincing as to nearly eclipse the genre's long association with controversial religious radicalism, anti-authoritarianism, and populism. To be sure, the genre's demotic energies discernibly pulsate in these sentimental novels about the trials of lowly, powerless people seeking relief from the abuses of worldly authority, for in these texts hymns repeatedly enable the dissolution of social hierarchies. However, these depictions often stop short of fully embracing the lively contemporary culture of populist hymnody and manufacture an image of hymnody that is denuded of its unsavory associations and brought in line with conventional notions of propriety and modesty. What emerges in these engagements-both in fictional depictions of hymn culture and in actual forays in hymn writing-is a syncretic compromise that tempers the form's inherent populism with an insistence on decorum and gentility. In presenting hymnody as fully respectable, this negotiation allayed lingering generic doubts and aided in the acceptance of hymns into the Protestant mainstream. At the same time, the domestication of hymnody enabled mid-century literary women to traverse the very standards of propriety they promoted and to position themselves as figures of substantial religious authority in their own right.

\section{THE RADICAL POPULISM OF DEVOTIONAL SONG}

While hymn singing today may seem wholly conventional, hymns are a fairly new addition to Anglo-American Christian worship, despite their considerable biblical precedent. The Hebrew Bible amply endorses the singing of religious lyric, as with Psalm 33.3, "Sing to [the Lord] a new song, / play skillfully on the strings, with / loud shouts," and Paul likewise urged his readers to "sing psalms and hymns and spiritual songs with 
thankfulness in your hearts to God" (Col. 3.I6). These explicit endorsements notwithstanding, hymns were often regarded with suspicion because of the idiosyncrasies of their content and composition. Unlike psalms, hymns diverged from the biblical script, and, as the products of authors lacking the august pedigree and divine sanction of the psalmist, hymns were deemed acceptable for private devotional use but inappropriate for congregational worship, for authorities in the Established Church feared that hymns might broadcast ideas of faulty theology. The Protestant Reformation invigorated interest in hymnody because it provided a vernacular forum for common people to recount and celebrate religious experience without the intercession of clerical authority. Martin Luther himself was a prolific hymnist, and the German-language Protestant world enjoyed a vibrant culture of hymnody that would not flourish in AngloAmerica until the nineteenth century. ${ }^{\mathrm{I}}$ Though Elizabeth I formally permitted hymns in I559 and even composed hymns herself, the genre failed to find widespread favor among both conservatives and reformers. John Galvin insisted that scripture alone provide content for congregational worship, a position shared by Anglican conservatives, who would shun hymns in favor of psalmody, the singing of metrical translations of the psalms. ${ }^{2}$ In practice, psalmody did not typically foster the joy and gladness described in the Bible as characteristic of religious song. Clergy habitually complained about the poor quality of their congregants' singing; even John Wesley, the foremost advocate of hymnody, complained about worshippers' singing in his instructions that congregants should "Sing modestly. Do not bawl . . . that you may not destroy the harmony; but strive to unite your voices together, so as to make one clear melodious sound." In some instances, clergy limited congregational participation altogether and consigned recitation to an individual chorister, a choir, or to a precentor, a clergyman charged with supervising service music. In addition, psalms were traditionally recited in successive order throughout the ecclesiastical year, regardless of the text's relevance to feast days or the weekly sermon. The Bay Psalm Book (I640), the first English-language book printed in North America, was issued to satisfy the Calvinist belief in the "necessity of the heavenly Ordinance of singing 
Scripture Psalmes in the Churches of God," though the translators openly acknowledged that their versions were aesthetically wanting and were not "always so smooth and elegant as some may desire or expect." "In all of these ways, psalmody typically reified the clericalism and ceremonial formalism that the Protestant Reformation so vehemently combated, and the transition from psalmody to hymnody was associated with heterodox criticism of clerical mediation and rote religious custom. Where psalmody routinized worship, hymnody aimed to activate worshippers, both by eliciting joyful, melodic participation in devotional song and by accepting lay-authored religious lyric as suitable content for worship service. The remoteness and alienation fostered by psalmody were succeeded by a new form that sought to engender engagement, emotion, and intimacy.

From the very outset, English-language hymnody was advocated by, and thus associated with, religious dissenters and innovators. Though most commonly embraced by people on the religious and social periphery, congregational hymnody was so problematic that even Nonconformists found it objectionable, though it found some advocates, among them Baptist minister Benjamin Keach (I640-I704), who originated the idea of including hymns in congregational worship, and writer and theologian Philip Doddridge (I702-I75I), whose colleague and friend Isaac Watts (I674-I748) would become the first major contributor to English-language hymnody. ${ }^{5} \mathrm{~A}$ dissenter and evangelical Nonconformist who suffered discrimination for his refusal to vow allegiance to the Church of England, Watts was a dedicated educational reformer who authored numerous textbooks and pedagogical guides that exerted influence in North America and England well into the nineteenth century. His collections of devotional song-Horae Lyricae (I706-09), Hymns and Spiritual Songs (I707), Divine and Moral Songs for the Use of Children (I7I5), and The Psalms of David Imitated in the Language of the New Testament (I7I9)-would become the foundation of the Protestant English-language hymn tradition. His influence on the genre cannot be overstated, for he not only energized this new devotional form but also produced a vast literary corpus that would become the standard of craftsmanship against which later hymnists would be measured. Though Watts himself was 
a Congregationalist, he would diverge from Calvinist doctrine by recommending a departure from psalmody, a decision he would explain in the preface to Hymns and Spiritual Songs:

in these last Days of the Gospel we are brought almost within sight of the Kingdom of our Lord; yet we are very much unacquainted with the Songs of the New Jerusalem, and unpractised in the Work of Praise. To see the dull Indifference, the negligent and the thoughtless Air, that sits upon the Faces of a whole Assembly, while the Psalm is on their Lips, might tempt even a charitable Observer to suspect the Fervency of Inward Religion; and it is much to be feared, that the Minds of most of the Worshippers are absent or unconcerned.

He continued, "That very Action, which should elevate us to the most delightful and divine Sensations, doth not only flatten our Devotion, but too often awakens our Regret, and touches all the Springs of Uneasiness within us." The central problem, according to Watts, is that psalms are not actually Christian: though they may express joy in the Lord and forecast the advent and sacrifice of Christ, the psalm as a form "hath something in it so extremely Jewish and cloudy, that it darkens our Sight of God the Saviour." As a genre originating in the religious antecedent of Christianity but not directly emanating from it, the psalm is too much at a remove from, and even detrimental to, the emotional immediacy and intimacy that Watts believes ought to result from devotional song, and its recitation too much privileges historical convention and precedent to be emotionally potent in the present. For Watts, circumstances demanded the formation of a new devotional genre.

The radicalism of this endeavor was furthered by Watts's hope that modern congregational song could contribute in a meaningful way to the dissolution of the divisions-denominational, social, and economic-that separate Christians from each other. The simple act of publicly joining in song and affirming common beliefs, Watts averred, could dissolve worldly 
differences in denomination or class. For example, in the preface to Hymns and Spiritual Songs, he explains that his hymns "have avoided the more obscure and controverted Points of Christianity, that we might all obey the Direction of the Word of God, and sing his Praises with Understanding, Psalm 47.7. The Contentions and distinguishing Words of Sects and Parties [have been omitted], that whole Assemblies might assist at the Harmony, and different Churches join in the same Worship without Offence." 7 In joining voices in song, hymns may encourage this unity by avoiding divisive matters and inviting worshippers merely to "sing [God's] Praises with Understanding." Likewise, in Divine and Moral Songs for Children, Watts expressed his hopes that "children of high and low degree, of the Church of England or Dissenters, baptized in infancy or not, may all join together in these songs." Hymns, for Watts, ought to "be of the more universal use and service," and the task of the hymn is to spark direct, unmediated feelings of love for the Lord and to unite fellow believers in shared belief, regardless of provenance or sect. ${ }^{8}$

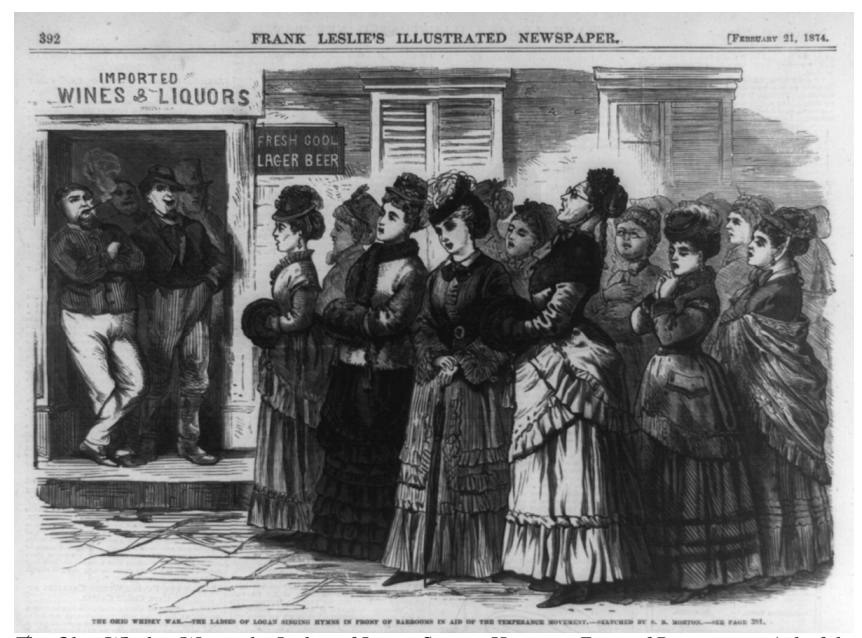

The Ohio Whiskey War - the Ladies of Logan Singing Hymns in Front of Barrooms in Aid of the Temperance Movement. From Frank Leslie's Illustrated Newspaper, (February 2I, I874): 392. Courtesy of Library of Congress, Pictures and Photographs Division. LC-USZ62-90543.

To these ends, Watts deliberately crafted his hymns in accessible, simple language apprehensible even to what he called "the Vulgar Capacities." As he explained in Hymns and Spiritual 
Songs, he omitted from his hymns "Lines that were too sonorous, and [has] given an Allay to the Verse, lest a more exalted Turn of Thought or Language should darken or disturb the Devotion of the weakest Souls." ${ }^{9}$ More elevated language, he feared, might confuse or alienate less educated worshippers and thereby reinstate the divisions of class and education he hoped his hymns might diminish. Indeed, this egalitarianism underlay the excision of theological cerebrations from his hymns and the liberal inclusion of forthright emotional prompts: in the culture of evangelicalism in which Watts lived and wrote, it is affective sincerity-not theological sophistication-that distinguishes the genuine Christian, and intensity of feeling is available to everyone, regardless of social status. He thus filled his hymns with emotional appeals to emphasize common sentiments amid differing social classes and widen the reach of Christianity among the less privileged.

The association of hymnody with the heterodox leveling of hierarchy would be confirmed with the rise of Methodism under the leadership of John and Charles Wesley (I703-9I and I707-88). Though the Wesley brothers always remained ordained Anglican clergy, they diverged from the Established Church in their ardent pietism, denouncing religious complacency and promoting an energetic spiritual life characterized by diligent striving for greater nearness to God. The Wesleys were unrelenting in their evangelical fervor and developed an array of unorthodox pastoral techniques-such as open air preaching, peripatetic clergy, and lay ministry-that were designed to extend Christian ministry beyond the confines of the pulpit and reach the multitudes in their own environment. Methodism quickly developed a reputation among conservatives for an indecorous populism because of its efforts to recruit the lower classes and willingness to allow common citizens untrained in theology or oratory to preach and perform ministerial duties. Methodist laypeople were permitted and even expected to confess their sins to each other rather than to clergy, enjoin each other to greater holiness, and offer prayer for their brethren. The Methodist democratization of worship saw the creation of prayer meetings and "love feasts" in which attendees were required to offer public testimony of 
their religious conversions, confirming that, for the Methodists, personal religious conviction alone provided sufficient qualification for the performance of clerical duties. Though John Wesley wavered on this issue, the Methodists were known to allow women to preach, despite the Pauline edict forbidding women from speaking in church. ${ }^{10}$ The Methodist dispersal of clerical authority was accompanied by the erosion of traditional church decorum; the conventional solemnity of worship services gave way to famously raucous, unruly revival meetings, in which worshippers writhed, groaned, wept, shouted for joy, or unashamedly replied to preachers. ${ }^{\text {II }}$ This breakdown of hierarchy extended even into Methodist theology, which rejected the predestinarian belief that God attributed salvation only to the elect, regardless of their apparent merit. For the Methodists, salvation is within reach of everyone and can be attained through faith and diligence.

Methodist populism was significantly augmented by the Wesley brothers' recognition of hymnody as a legitimate form of public worship and means of doctrinal dissemination. ${ }^{12}$ As an Anglican trained to favor psalmody, John Wesley first encountered hymnody during his missionary travels to North America in the I730s. On his journey to the colonies, he observed the joyous hymn singing of some travelling Moravians, members of a German pietist sect renowned for its hymnody, and Wesley came to believe that singing could both generate and express sincere, powerful religious feeling. In an effort to spark such a response, Wesley in I737 published in Charleston, South Carolina, A Collection of Psalms and Hymns, the first hymnal designed for Anglican worship and the first hymn collection published in North America. ${ }^{13}$ In thus deviating from Anglican doctrine and practice, Wesley faced criticism and even formal censure; Anglican conservatives appealed to a Grand Jury in Georgia and accused Wesley of "introducing into the church and service at the altar [the] compositions of Psalms and Hymns not inspected or authorized by any proper judicature." I4 This reception amply illustrates what was at stake in the rise of hymnody. As a bottom-up, populist genre that enabled common people to have an active voice in church, whether by singing or by writing such works themselves, hymns threatened to cir- 
cumvent, compromise, and even erode established authority. Indeed, the common language of song enabled the Methodists to reach the lower classes, whose inability to pay pew fees kept them away from church but who nonetheless encountered potent ministry through memorable tunes and repetitive lyrical phrasings. According to Gareth Lloyd, Methodist hymns could be heard "not just in chapels, but in the workplace, the home, and the street," and thereby carried out the Methodist plan of extending the church beyond the delimited confines of sanctified houses of worship and permeating daily life with Christian piety. ${ }^{15}$ Methodists became famous-even infamous-for their energetic, lively hymn singing, and popular hymnody became a Methodist trademark. For that reason, other denominations were slow to embrace hymnody because of the association of Methodism with people on the social margins.

In North America, hymns found a popular audience through their promotion at Methodist camp meetings, in which singing was notoriously boisterous. Congregational song became part of the attraction, and hymns enabled huge numbers of people-across class, gender, age, and race-to unite publicly in worship and voice. ${ }^{\mathrm{I}}$ After famed Methodist preacher George Whitefield introduced the hymns of Isaac Watts to North America, revivalism was able to overcome the long-standing resistance of the more orthodox denominations, with the Congregationalists finally embracing the hymns of Isaac Watts in the late eighteenth century and the Presbyterians in the early nineteenth ${ }^{.17}$ By the I820s, it became clear that congregational hymnody was no passing fad but a permanent addition to Anglo-American Christianity. ${ }^{18}$ The immense popularity of Methodism left more conservative denominations feeling endangered, and in I837 the liberal wing of Presbyterians, the so-called New School, responded by adopting some of the untraditional evangelical practices, the so-called "New Measures," employed in revivals. ${ }^{19}$ The competitive adaptation to Methodism included a broad denominational willingness to incorporate hymnody into worship services, which yielded a more dynamic, passionate form of worship that temporarily shifted the focus from the clergy to the congregation by enabling active public participation. 
By the second quarter of the nineteenth century, various Protestant denominations began to compile and issue their own sectarian hymnals, a genre that, by its very nature, undermined the integrationist ambitions of early hymnists by fortifying sectarian divisions. ${ }^{20}$ Denominational hymnals sought to oversee this populist form and reinforce the primacy of hierarchical authority. The hymnal editor, typically a member of the clergy, scrutinized hymns for content and quality before allowing them admission to their collections. ${ }^{21}$ Texts were appraised for their literary caliber, broad appeal, and theological regularity, and, because the hymn had long been associated with egalitarianism and populism, the hymnals of more conservative denominations sought to reinstate criteria tethered to exclusivity and privilege. For example, conservative denominations declined to include in hymnals the songs favored in revivals and camp meetings. These populist hymns were typically characterized by features that enabled them to be accessible to a wide span of the public, such as simple vernacular lyrics, repeated refrains, and reliance on popular tunes. These songs were both improvised spontaneously and composed expressly for revivals, as with Joshua Leavitt's collection, The Christian Lyre (I83I), which functioned as a musical companion to Charles Finney's revival meetings and consequently went through 26 editions within fifteen years. ${ }^{22}$ While hymns of this genre would find a receptive home among Methodists and Baptists, the Congregationalists, Episcopalians, and Presbyterians typically regarded them as unsuitable for formal worship and selected instead hymns whose more sophisticated poetic lyricism and musical arrangements exhibited discernment and polish. For example, in contrast to the wide use of popular tunes in camp meeting hymns, hymn editors and arrangers from these latter denominations frequently enlisted themes by classical composers such as J.S. Bach, Beethoven, Hayden, and Mendelssohn as accompaniment to hymn lyrics, a decision that raised the taste and pedigree of this form.

Asahel Nettleton's Village Hymns for Social Worship (I824) is an illustrative case in point. In I820, the General Association of Connecticut determined that "the prosperity of religion within their limits" warranted the creation of a hymn book, especially 
in light of "the prevalence of revivals," and Nettleton, a Congregationalist clergyman and an itinerant revivalist, collected material for this new collection by researching popular songs and soliciting material from amateur writers. Though never intended for use in congregational worship, Village Hymns is a landmark work that sought to diversify hymnody beyond the opus of Isaac Watts, sparked the growth of missionary hymnody, and tried to promote the careers of home-grown American hymnists. ${ }^{23}$ Nettleton's distillation of contemporary hymnody found a receptive audience, and in three years it went through seven editions. ${ }^{24}$ At the same time, his collection is motivated by a desire to reinstate literary standards and expunge earthy revival hymns from the canon. In his preface, Nettleton writes that he "had hoped to find, in the style of genuine poetry, a greater number of hymns adapted to the various exigencies of revival. Laborious research has, however, led me to conclude, that not many such compositions are in existence." Though he concedes that revival hymns "have been sung with much pleasure and profit," he deems such songs "ephemeral" because they are "entirely destitute of poetic merit." Revival hymns, according to Nettleton, are "utterly unfit for the ordinary purposes of devotion," and thus "the safest course is to leave them generally out." ${ }_{25}$ For Nettleton, literary caliber and taste justified the restoration of exclusionary standards and the omission of populist revival hymns from an embryonic canon.

Hymnody nonetheless eluded these efforts to impose supervision and refinement. ${ }^{26}$ Public appetites for non-denominational hymnbooks only expanded, and the populist hymns that failed to meet Nettleton's standards grew exponentially in number and popularity. The revival of $1857-58$ and the revivals led after the American Civil War by preacher Dwight Moody and his musical collaborator, Methodist composer Ira D. Sankey, sparked enthusiasm for hymns in the revival style, which Sankey termed "gospel hymns." The great success of Sankey's collection Gospel Hymns and Sacred Songs (1875) confirmed the survival and even popularity of devotional song geared to less elite sensibilities, despite the efforts of genteel editors and arrangers to elevate the literary and musical standards of hymnody. ${ }^{27}$ Gospel hymns were so popular that, by the century's end, something 
like I500 gospel songbooks alone had been published. ${ }^{28}$ Nor did hymnody conform to denominational and clerical strictures but seeped outsides those bounds, pervading American public and private life well beyond the reach of clergy and hymn editors. As published texts, hymns made their way into scrapbooks, journals, and letters of the period, and were integrated within the daily lexicon of evangelical Christians. ${ }^{29}$ Hymnals were upheld as the only text other than the Bible necessary for professing Christians. Hymn lyrics and tunes were an essential source of poetry and music for Americans in the nineteenth century, and the singing or recitation of hymns were common leisure pastimes in American homes. In addition to providing inspiration or consolation to readers, hymns became a popular literary form in private writing, used by ordinary people seeking to transcribe, document, and order their religious feelings and experiences. ${ }^{3 \circ}$ Henry Ward Beecher, the nation's leading minister in the mid-century and the era's foremost advocate of congregational hymn singing, affirmed the pervasiveness of devotional song in daily life and its particular favor among people of humble status: "We carry [hymns] with us upon our journey. We sing them in the forest. The workman follows the plow with sacred songs. Children catch them, and [sing] only for the joy it gives them." ${ }^{3}$

\section{पII \\ II. READING HYMNODY IN NINETEENTH-GENTURY FICTION}

While "gospel" hymns in the revivalist style would continue to be perceived as déclassé among more conservative denominations, hymns would eventually overcome long-standing prohibitions and be widely included in congregational worship. Two landmark publications in the I850s are generally regarded by hymnologists as heralding the mainstream acceptance of hymns: the Plymouth Collection (I855) edited by Henry Ward Beecher and the Sabbath Hymn Book (I858) edited by Andover Seminar professor Edwards A. Park, Austin Phelps, and hymnist Lowell Mason. However, in the complex history of English-language hymnody, women writers of the mid-century played a vital, 
if overlooked, role in mollifying concern about the genre's lingering associations with social unrest and in imparting the respectability necessary for its mainstream acceptance. Well before the publication of these two renowned hymn collections, women writers did considerable work in refining the public image of and attitude toward hymns. With the inclusion of countless scenes of hymn singing and reading in women's and children's literature, writers such as Stowe and Warner implicitly refashioned and domesticated the hymn, tempering its associations with the controversial public demonstrations of revivalism and bringing it in line with the private, modest pieties of normative mid-century femininity that these women were so instrumental in codifying and circulating. While the status of hymns might still be vexed in the church-going lives of nineteenth-century readers, in the universe of sentimental fiction hymns are fully respectable and wholesome. In this respect, prominent women writers endeared readers to hymnody well before clergy gave their public benison. But in crafting a virtuous image of hymnody, these women writers did not entirely expurgate its long-standing associations with social insurgency and egalitarianism. Rather, close attention to sentimental depictions of hymnody can allow us to see how these writers provided assurances of hymnody's benefits and virtues white retaining some of its populist connotations. As depicted in innumerable novels, hymns do remain the rightful property of lowly people, who turn to these songs for help when worldly authority fails to offer assistance in times of trouble. Hymns in these novels enable people on the social margins to raise their standing in the world, whether morally or materially, and stake a claim on the authority often misused by those in power. In this respect, these writers sanction the laity-centered, populist hymnody that commenced with Watts and animated the Wesleys and their revivalist successors. However, their depictions are often characterized by a distinct effort to raise the form's stature. In mid-century female-authored fiction, hymns are less the vehicle of populist rabble rousing and faulty theology, as conservatives feared, than the means by which marginal, struggling people can better themselves and adapt to normative standards of respectability and decorum. Hymns, that is, en- 
able the betterment of the lowly, not the spread of lower-class popular culture. In support of this contention, these writers typically ignore revival or camp meeting hymns, and highlight instead hymns marked by poetic craft and aesthetic sensibility. Hymns need not cater to the lowest social denominator, these women suggest, but may enable self-betterment, whether morally, intellectually, or socially.

For example, in Warner's The Wide, Wide World, hymns function like an underground ministry, exchanged casually among believers and offering impromptu religious instruction and inspiration in remote places far from the pulpit: on a ferry, in a rural farm, in the household of apostates. Hymns figure prominently in the moral and religious education of orphan Ellen Montgomery, and throughout the novel she persistently turns to the hymnal given to her by a benevolent stranger, finding comfort and consolation there in times of trouble. Key moments in Ellen's maturation are usually signaled by the reprint of hymn lyrics: for instance, John Newton's hymn "Poor, Weak, and Worthless Though I Am" inspires Ellen to take responsibility for her role in a squabble with her brusque aunt, Miss Fortune, and shortly thereafter Charles Wesley's hymn "A Charge to Keep I Have" prompts Ellen to adopt "untiring gentleness, obedience, and meekness" in her future dealings with Miss Fortune. ${ }^{32}$ Indeed, the novel was so replete with hymn lyrics that it would provide the inspiration for a genuine song cycle, W.H. Bellamy and C.W. Glover's Lyrics from "The Wide, Wide World" (I853), which adapted some of these pivotal scenes into dramatic songs. While Warner leaves little doubt about the morally and spiritually transformative powers of hymns, the novel repeatedly suggests that hymns may effect change in social hierarchies as well. In a particularly suggestive scene, Ellen ministers to clergyman Mr. Humphreys after the death of his daughter, Alice, by singing hymn after hymn. In a pared-down depiction of the capacity of hymns to activate the worshipper and render the clergy passive, this episode reveals how hymnody may upend traditional hierarchy, allowing orphan girls the wisdom and poise to offer counsel to religious authority figures. The transformative power of hymns is likewise visible late in the novel after Ellen moves to Scotland to live 
with her mother's family, who consider her piety distasteful and demand that she renounce her attachments to the Humphreys family. In one scene, her private hymn singing causes her domineering uncle, Mr. Lindsay, to inquire, "Is all your heart in America, Ellen, or have you any left to bestow on us?" "33 In this instance, Lindsay detects in her hymn singing a threat to his primacy and questions whether other emotional loyalties may be undermining his rule, an assumption that bespeaks the associations of hymnody with anti-authoritarianism and populist self-governance.

At the same time, the novel cleaves to a distinctly genteel model of hymnody. Though in her I864 novel, The Old Helmet, Warner would portray both congregational hymnody and camp meeting song as legitimate expressions and incitements of faith, The Wide, Wide World envelops hymnody within the mantle of conventional propriety and politesse. In the first place, the novel gives decided preference to the class of hymns associated with more conservative denominations, reprinting only the stately, poetically sophisticated lyrics of such hymnists as Philip Doddridge, John Newton, Augustus Toplady, and Charles Wesley, and omitting revivalist and camp meeting hymns altogether. Though Warner in this work declines to offer an outright opinion on the propriety of public song, the novel secretes hymnody behind closed doors, presenting it as material appropriate for private reflection and intimate conversation rather than public performance. ${ }^{34}$ In thus avoiding any scenes of genuinely public hymn singing, the novel domesticates hymnody and brings it into alignment with contemporary feminine, middle-class morals, which privilege the private over the public, the written over the oral, and the refined over the spontaneous. ${ }^{35}$ Directly countering anxiety that hymns might incite the frenzied, unfettered emotional climate of revivalism, Warner presents hymns as enabling instead an antipodal affect characterized by self-control and the dutiful suspension of private feelings: for example, the reading of hymns inspires Ellen to hold her tongue and behave with perfect composure. Hymns enable restraint and self-censorship, not unseemly public emotional intemperance. ${ }^{36}$ 
While hymns play a central role in Ellen's religious and moral instruction, they no less participate in her social and intellectual refinement, allowing her to receive, albeit in an abbreviated and adapted way, the education expected of young ladies of privilege. Whereas the public singing of camp meeting songs might signal Ellen's precipitous social and economic decline into a milieu often denounced as vulgar by the social elite, the private reading and singing of canonical, time-honored hymns indicate instead a commitment to the predilections for discernment and self-mastery associated with respectability and even social ascent. In a household with little appreciation for education, literary matters, or religion, hymns provide Ellen with carefully curated reading material and contribute to her development into a sensitive, appreciative reader, a skill expected of a young woman of respectable birth but one that she would otherwise struggle to cultivate living with Miss Fortune. The habitual reading of hymns fosters the perception of reading not as idle entertainment, an attitude that her future husband, seminarian John Humphreys, will warn her against, but instead as a means of self-improvement and moral development. And though her circumstances prevent her from having the musical education expected of accomplished young ladies, hymns serve as a pious substitute for a secular pastime, both in allowing her to practice her singing skills and to conduct the private domestic recitals common among affluent households. In all of these ways, Warner affirms that, however much hymns may enable the contestation and reversal of social authority, they may preserve middle-class ideals of taste and decorum, effectively improving and refining those with whom they come into contact. In this respect, she suggests that hymns may level authority by enabling social mobility.

The fiction of Harriet Beecher Stowe registers similar engagement in the history and complications of hymnody. In her I862 novel Agnes of Sorrento, Stowe summarized the history of hymns, recounting how "the Moravian quaintness and energy [intermingled] with the Wesleyan purity and tenderness," and she documents the genre's history with transcriptions of innumerable medieval hymns by such writers as St. Bernard of Clairvaux. Lest her Protestant readers balk at these Catholic 
lyrics, she clarifies that, "in its English dress, [one of these hymns] has thrilled many a Methodist class-meeting and many a Puritan conference, telling, in the welcome they meet in each Christian soul, that there is a unity in Christ's Church which is not outward,--a secret, invisible bond, by which, under warring names and badges of opposition, His true followers have yet been one in Him, even though they discerned it not." ${ }^{77}$ According to Stowe, hymns still possess the power to abet unity and dissolve worldly differences. Oldtown Folks (I869) documents the early American suspicion of hymnody's extra-scriptural character, as with the remark of the minister Dr. Lothrop, upon hearing a congregant recite a hymn verse, "that, madam, is not the New Testament, but Dr. Isaacs Watts, allow me to remind you.'" Upon the congregant's assurance that Watts "'got it from the Bible," Lothrop replies, "'Yes, madam, a very long way from the Bible, allow me to say." " ${ }^{8}$ In her I87I story "The First Christmas of New England," she describes the devotional singing of early American settlers, reminding her readers that "the treasures of sacred song which are the liturgy of modern Christians had not arisen in the church. There was no Watts, and no Wesley, in the days of the Pilgrims," but only Psalters. ${ }^{39}$ In Uncle Tom's Cabin, Stowe concurs with evangelical opinion that psalmody is too aloof and formal to incite genuine religious feeling. ${ }^{40}$ In the novel's first chapter, when Mr. Shelby coaxes little Harry Harris to entertain the slave trader Haley, he prompts the child to "show us how old Elder Robbins leads the psalm," and the boy "drew his chubby face down to a formidable length, and commenced toning a psalm tune through his nose, with imperturbable gravity." ${ }^{\mathrm{I}}$ The transformation here of a gleeful, energetic child into a dour, serious church elder implicitly speaks volumes about the joyless formality and emotional impassivity of psalmody. But especially suggestive is its practice among white self-interested slave-owners for whom Christianity seems be little more than a torpid weekly ritual devoid of feeling or conviction. Stowe commits the rest of the novel to defending her ardent contention that sincere, impassioned Christian faith renders slavery abhorrent and intolerable, but she begins her novel with a parodic portrait of the sterile psalmody practiced among slaveholders to suggest that, 
in failing to spark powerful emotion, such apathetic religious routine is indirectly responsible for the national sin of slavery.

In accord with the long-standing associations of hymnody with the struggles of the social periphery, Stowe dwells in some detail on the lively evangelical hymnody of slave congregations, which, unlike psalmody, proceeds "to the evident delight of all present." Just as Warner presents hymns as able to level hierarchies and afford Ellen authority over herself and her male social betters, so Stowe also channels the subversive history of the genre into her novel. In an early scene of a slave meeting at Tom's cabin, one elderly slave participant is visibly transformed by the experience of hymn singing. She remarks, "'I'm mighty glad to hear ye all and see ye all once more, 'cause I don't know when I'll be gone to glory; but I've done got ready, chil'en; 'pears like I'd got my little bundle all tied up, and my bonnet on, jest a waitin' for the stage to come along and take me home." "42 Hymns cause her to see her worldly travails as temporary circumstances on her larger life journey to salvation, and thus afford her comfort and relief. ${ }^{43}$ As Stowe describes it, the singing of hymns allows the slaves to resist the despotic rule of their captors by reminding them that they follow a lord whose power dwarfs that of their masters and who promises redemption and reward at the conclusion of their worldly suffering. Tom's dealings with the brutal slave owner Simon Legree bear ample witness to this belief. In one pivotal scene, Legree tempts Tom to "join my church" by abandoning his faith and becoming one of Legree's willing slave minions. To that end, Legree mocks Christianity as a "mess of lying trumpery" and undermines Tom's hope for redemption by reasserting the finality of his own authority. '"The Lord an't going to help you," Legree taunts; " if he had been, he wouldn't have let me get you!" According to Legree, even God's authority cannot be relied upon for support or comfort, and so Tom would be well advised to grasp whatever worldly help he can find: "Ye'd better hold to me," Legree says; "I'm somebody, and can do something." Tom feels momentary despair, his "dejected soul" sinking "to the lowest ebb," and he responds by singing John Newton's hymn "Amazing Grace," which was famously composed after conversion caused him to renounce his work as 
a slave trader. Stowe excerpts several lesser-known verses that, in showcasing divine might, implicitly undermine the power of worldly authority:

The earth shall be dissolved like snow, The sun shall cease to shine; But God, who called me here below, Shall be forever mine.

And when this mortal life shall fail, And flesh and sense shall cease, I shall possess within the veil A life of joy and peace.

When we've been there ten thousand years, Bright shining like the sun,

We've no less days to sing God's praise

Than when we first begun. ${ }^{44}$

This depiction of God's sublimity restores Tom's equanimity and, in implicitly constituting enslavement as a temporary trial to be endured, consequently diminishes Legree's authority. Tom feels "an inviolable sphere of peace," and "[s]o short now seemed the remaining voyage of life,--so near, so vivid, seemed eternal blessedness, - that life's uttermost woes fell from him unharming." The hymn renders him impervious to "insult or injury" but as a result further riles Legree to employ greater violence in an effort to subordinate Tom. Legree soon thereafter becomes enraged upon overhearing Tom sing Isaac Watts's hymn "When I Can Read My Title Clear," which defiantly asserts that, "Should earth against my soul engage, / And hellish darts be hurled, / Then I can smile at Satan's rage, / And face a frowning world" (557). In forecasting a time when Tom "can read [his] title clear," the hymn substantiates Tom's hope that he will eventually own himself, even if only in the afterlife, and the hymn thereby confirms that Simon Legree's authority is merely temporary. In this way, the hymn enables the 
lowly, powerless slave to delimit the authority of those in power over him and even to claim some of that authority for himself.

That said, Stowe by no means suggests that hymns incite slave uprisings or violent rebellion, for, in enabling slaves to direct their hopes for freedom to the afterlife, hymns restrict slave insubordination to the affections and aspirations. In a novel about a culture that most Northern readers would never know directly, hymns function as a distinctly normalizing, familiarizing force that combats reader estrangement and abets sympathy and identification. Similar to the way a photographer might include in an image a commonplace object such as a coin to indicate scale, Stowe uses hymnody to present slaves as recognizably upright Christian brethren who, in reciting and reflecting on hymns in times of trouble, presumably replicate the worship practices and hymn preferences of readers. For example, she takes care to clarify that slaves habitually sing "the well-known and common hymns" by such eminent hymnists as Newton and Watts, suggesting that slaves share a hymn canon with readers and thus possess a developed literary sensibility sufficient to appreciate such refined poetic lyrics. At the same time, Stowe acknowledges that the "wild and spirited" practices and styles of slave hymnody may not comport with reader notions of propriety. ${ }^{45}$ Lest the reader dismiss such songs out of hand, she clarifies that the emotional vibrancy of slave hymnody, however uncouth a conservative reader may find it, actually enables selfcontrol, patience, and forbearance among slaves, allowing them to bear their burdens with pious resignation rather than bitter disillusionment or even violence. As with the fortitude of the old slave woman at the meeting and Tom's renewed courage after singing a hymn by Newton, hymns foster a self-command and restraint among slaves similar to that of Ellen Montgomery. And in conformity with conservative opinion, Stowe depicts slaves' hymnody as a largely domestic practice, as with Tom's private recitation of "Amazing Grace" and the gathering held in Tom's cabin shortly before his departure. Though some slave hymns may seem "wilder" than what readers are used to, hymns in Uncle Tom's Cabin both affirm and produce the religious respectability of slaves. 
She openly addressed concerns about the taste and propriety of such populist hymnody in Dred: A Tale of the Great Dismal Swamp (I856), her follow-up to Uncle Tom's Cabin. Midway through the novel, a group of slave-owning Southerners ventures to a camp meeting in search of amusement and spectacle. After a member of their party succumbs to the altar call the night before, they fall into a discussion about the propriety of such emotional public declarations of faith, hymns and song among them. At the heart of the discussion is the perceived incongruity of gentility with such open avowals of feeling. Anne Clayton, a mannerly and reserved young woman, contends that such declarations are "an invasion of that privacy and reserve which belong to our most sacred feelings." In her insistence that "there is a reserve about these things which belongs to the best Christians," Anne voices skepticism about the public expression of religious feeling, adding that, as an extension of this belief, she "always had a prejudice against that class both of hymns and tunes'" favored at camp meetings. Her brother, the antislavery lawyer Edward Clayton, replies by defending the congregational songs of camp meetings, remarking that such songs are habitually "'misjudge[d]" by "refined, cultivated women . . who are brought up in the kid-slipper and carpet view of human life." 'According to Clayton, a sensibility defined by both financial privilege and domesticity makes well-to-do women particularly disinclined to appreciate songs associated with the public devotions of the masses, and he urges greater open mindedness toward religious expressions unhindered by such constraints. He urges Anne to overlook the informality or commonness of such works and to attend instead to the genuineness of their feeling. "What faith is there!" he exclaims. "What confidence in immortality! How could a man feel it and not be ennobled?" " ${ }^{46}$ Regardless of a hymn's content or origin, its sincere sentiments may improve and enrich one's character; such works, he argues, may perfect the religious life of even the most cultivated gentlewoman. In this way, Stowe seeks to allay anxieties about populist hymnody by asserting that they may affect the same civilizing ends as more elite hymns; despite the coarseness of their packaging, they need not be feared by religious traditionalists bound by class constraints. 
Louisa May Alcott's I877 novel, Under the Lilacs, similarly depicts hymns as a means of uplift for vulnerable, marginal people but endorses a hymnody rooted in conventional ideals of propriety. Under the Lilacs depicts the friendship of the middleclass Moss children with Ben Brown, a homeless boy who has run away from the circus in search of his lost father. In their efforts to socialize and reform Ben of his rough-and-tumble ways, the Moss children introduce him to the pious domestic rituals of the Sabbath, which include privately studying and memorizing a hymn, but Ben's limited education causes him to recoil from the formal, elevated language of the hymns he finds. In response, the children encourage him to read a hymn written by Miss Celia, their kindly neighbor. The hymn reads as follows:

A little kingdom I possess,

Where thoughts and feelings dwell;

And very hard I find the task

Of governing it well.

For passion tempts and troubles me,

A wayward will misleads,

And selfishness its shadow casts

On all my words and deeds.

How can I learn to rule myself,

To be the child I should,-

Honest and brave, - nor ever tire

Of trying to be good?

How can I keep a sunny soul

To shine along life's way?

How can I tune my little heart

To sweetly sing all day?

Dear Father, help me with the love

That casteth out my fear!

Teach me to lean on thee, and feel

That thou art very near;

That no temptation is unseen,

No childish grief too small, 
Since Thou, with patience infinite,

Doth soothe and comfort all.

I do not ask for any crown,

But that which all may win;

Nor seek to conquer any world

Except the one within.

Be Thou my guide until I find,

Led by a tender hand,

Thy happy kingdom in myself,

And dare to take command. ${ }^{47}$

Ben warms to the hymn's informal, direct language, and he declares, "I like that! . . . I understand it, and I'll learn it right away." He soon memorizes the hymn and repeats it at bedtime for his evening prayers, in this way sanctioning the use of hymns in private devotion and efforts of self improvement. Just as the study of hymns signals Ellen Montgomery's growing maturation, so does this hymn mark a turning point in Ben's development, providing him with simple, comprehensible language to confess his failings and resolve to do better. This scene confirms hymnody's affinity for people on the lower echelons of society-who in this case include children, orphans, and the uneducated poor-and the uses of hymns in their efforts to raise themselves up, both materially and morally. Indeed, this episode offers an implicit defense of populist hymns composed for less educated people, on the grounds that this constituency may not be able to understand more lofty texts, a concern that occupied Isaac Watts centuries before. The dramatic results of Ben's hymn study suggest that the lowliness of a text's register or style need not mitigate the text's ability to inspire uplift and improvement. And in accordance with the egalitarian heritage of hymnody, this hymn suggests that the ultimate "crown" of salvation is one "which all may win," though the hymn clarifies that the speaker aims not to topple or overturn established authority but instead to "conquer" the "world . . . within," through self-discipline and betterment. The hymn suggests that this struggle for self-mastery has wider 
social and political implications. ${ }^{48}$ To rule oneself is, in effect, to assume the authority of the ruler and to become a member of that elite class. That is precisely what happens in the novel: through a religious and moral education activated by the reading of a hymn, a homeless waif on the very bottom of society ascends into uprightness and respectability.

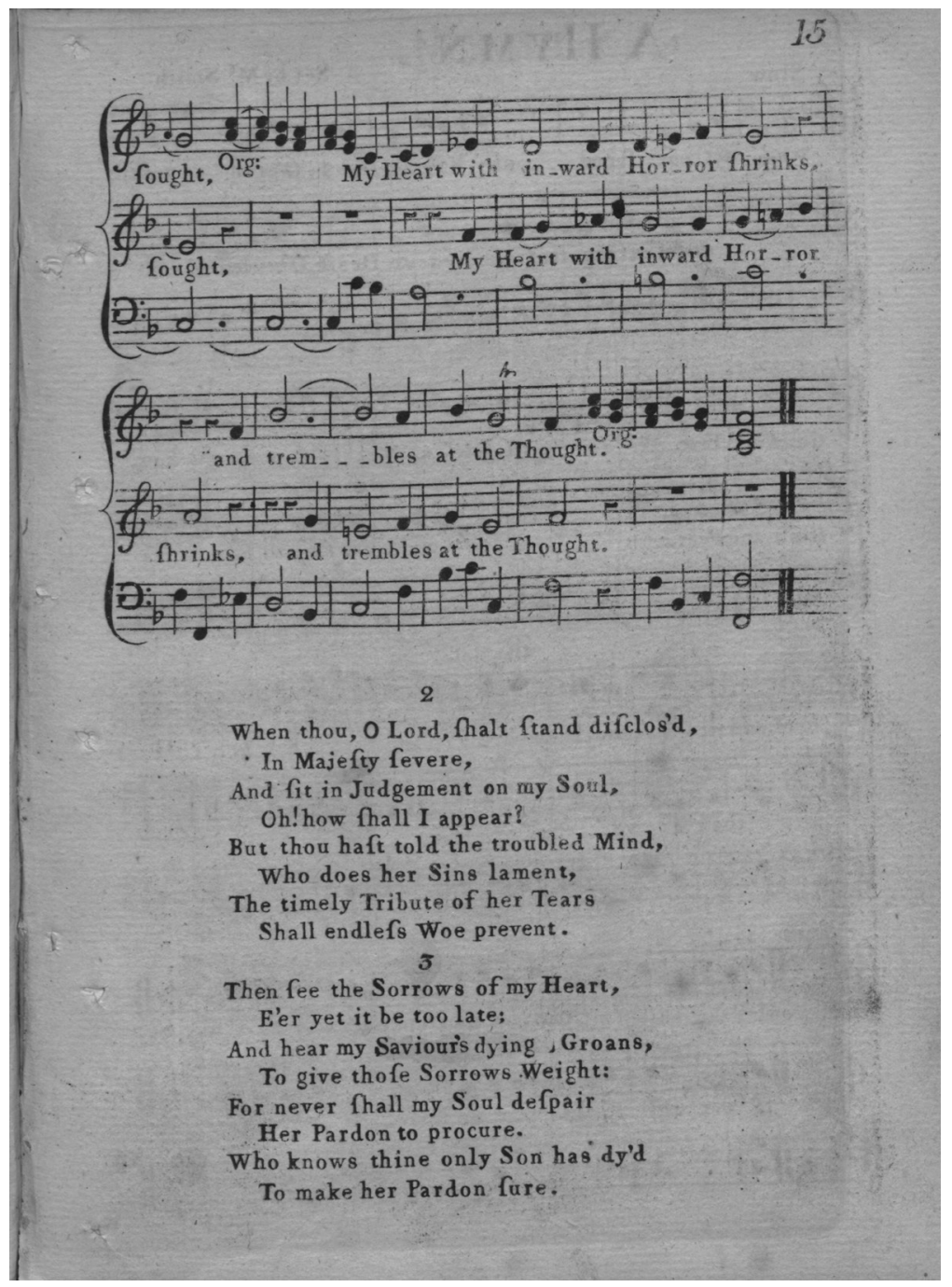

Hymn. Courtesy of Manuscripts, Archives, and Special Collections, WSU Libraries. 
Depicted thus in innumerable novels of the mid-century, hymnody became strongly allied to sentimentalism and was publicly constituted as a vital accessory to the female spiritual life. To be sure, these literary efforts to refine the public image of hymnody helped to consolidate the growing perception of hymns as a distinctly female-gendered genre, one well suited to the particular circumstances and trials of pious American women and one that came to have particular allure for women as both readers and writers. ${ }^{49}$ Women writers such as Stowe and Warner came to exert considerable influence not just on public attitudes toward hymns but also on hymns themselves, which came to adopt recognizably sentimental attitudes toward and beliefs about femininity, domesticity, and piety, and which consequently became particularly popular among American women. Hymnody, as a result, became a vital literary genre of sentimentalism, which in this form was able to move beyond the limits of the silent printed page to circulate in heretofore inaccessible locales such as churches and worship service. In that setting and in that form, it was poised to exert considerable influence on the religious beliefs and practices of worshippers and thereby become institutionalized and canonical. And in that respect, sentimental hymnody traversed the very gender traditionalism it so avidly touted, thereby extending the genre's associations, thanks to Methodism, with social disruption, which had for so long obstructed its mainstream acceptance.

The adoption of sentimental discourse within hymnody was made possible by a number of factors. According to June Hobbs, it was believed that sentimental femininity was particularly well suited to the genre of the hymn, for, women were believed to be better able to access and express feelings and thus to craft more emotionally potent hymns. ${ }^{50}$ In addition, the genre's characteristic pleas for divine assistance affect a posture of frailty and dependence that capitulates to conventional nineteenth- 
century notions of femininity, and, though neither women nor men hymnists used such language more than the other, the pervasive references to home in hymns about the afterlife indirectly rendered this form a celebration of a traditionally female space..$^{5 \mathrm{I}}$ The many domestic uses of hymns-in family prayer, the instruction of children, or household leisure activities-only furthered this gendered and generic kinship, as did the hymn's explicit emotionalism. In addition, the writing of devout poetry was deemed a desirable female accomplishment attesting to their taste, piety, and gentility, and hymnody was thus construed not as a transgression of biblical restrictions on female participation in church but as an expression of feminine traditionalism. ${ }^{52}$ Elizabeth Gray has observed that religious poetry proved an acceptable idiom for English women because of its formal resemblance to prayer, "a passive and private undertaking in which nineteenth-century women were held to excel." ${ }^{3}$ Harriet Beecher Stowe even claimed that the Christian hymn was the invention of the supreme paragon of sentimental femininity, as with her assertion that Mary's Magnificat in the New Testament was the first such work. ${ }^{54}$

In addition, domestic enclosure became a veritable generic requirement, with the belief that a hymn composed in a private moment of retiring self-reflection was more sincere, truthful, and effective in eliciting similar sentiments in others. ${ }^{55}$ This belief enabled women to contribute to hymnody while preserving their feminine bona fides, for a woman might respectably compose hymns in the privacy of her home, without venturing out into the public or compromising her domestic duties..$^{56}$ A hymn's private, amateur composition lent it credibility and respectability because, unlike the more polished work of professional songwriters or the rough compositions improvised at revivals, such works were believed to be the product of personal trial, sensibility, and genuine Christian experience rather than brash ambition or the spontaneous workings of ecstatic crowds. In this respect, the private domestic setting that imparted respectability to hymns in novels by Stowe and Warner became a generic marker of quality and emotional authenticity. ${ }^{57}$ Elizabeth Prentiss, a highly successful writer of numerous hymns and popular religious fiction, would capitulate to this expectation 
in an I870 letter, in which she wrote, "Most of my verses are too much of my own personal experience to be put in print now. After I am dead I hope they may serve as language for some other hearts," a statement that attests both to the use of the hymn form in private life and the belief that hymns originating in personal experience are more sincere and compelling than ones written professionally..$^{8}$ Prolific and beloved professional hymnist Fanny Crosby had to reckon with this assumption, and in one of her memoirs she claimed that all her many hymns derived not from canny professional craft but from private religious experience: she wrote, "That some of my hymns have been dictated by the blessed Holy Spirit I have no doubt; and that others have been the result of deep meditation I know to be true. . . Most of my poems have been written during the long night watches, when the distractions of the day could not interfere with the rapid flow of thought." 59 This belief gave rise to the enduring sub-genre of hymn histories, such as Nicholas Smith's Songs from the Hearts of Women (I903), which, by revealing the biographical details behind famous hymns, purported to verify their authenticity.

Despite these generic concessions to gender traditionalism, there is little doubt that women's participation was due above all to the genre's vexed history of populist inclusivity. Although women outnumbered men in church attendance and participation in auxiliary organizations, their lesser social status and prohibition from assuming clerical offices well suited them to a form long associated with the powerless and disadvantaged. ${ }^{6 \circ}$ With few other options available for women to take an active role in religious ritual, hymnody provided women with an unprecedented religious forum, one that, with congregational song, extended even into the church itself. Though female-authored hymns were in the main decorously modest and conservative in avowal, their sheer existence derives from and even extends the genre's tradition of social insurgency. As a genre born out of and still bearing the traces of demotic ambitions, it was amenable to anyone; one had only to be able to write about religious experience in such a way as to inspire recognition and feeling in others. Indeed, in the nineteenth century, anyone did write hymns, and the form was so genuinely bottom-up that 
professional writers, such as William Cullen Bryant and Oliver Wendell Holmes, contributed to the genre only after amateurs had already made it popular and fashionable. Historians of American hymnody have long pointed to this history of populist inclusivity as an etiology of female authorship, as with the career of celebrated hymnist Phoebe Hinsdale Brown. When Asahel Nettleton compiled his Village Hymns, he canvassed average citizens rumored to write religious poetry and solicited their work, a detail that confirms both the inclusiveness of this genre as well as its wide use among common people. In his inquiries, he encountered Brown, a housewife whose struggles with poverty and domestic cares motivated her to write devotional poetry in her quest for divine aid and strength. In I8I8 Brown wrote a poem in response to a nosey neighbor's probing query about her late-afternoon walks; originally titled "My Apology for my Twilight Rambles, Addressed to a Lady," the poem explains her need to "steal awhile away / From little ones and care, /And spend the hours of setting day / In gratitude and prayer."6r She kept the poem private for several years before Nettleton requested samples of her lyrics, and he would eventually edit this homely poem to expunge its personal references and include it in Village Hymns. ${ }^{62}$ Helped by this well-publicized narrative of private devotion, it became a genuinely popular hymn in the nineteenth century and was widely touted, if erroneously, as the first hymn published by an American woman. ${ }^{63}$

The collaboration between literary and religious forms resulted in the particular popularity of hymns among women. Though the pulpit had long been off limits for women, hymns had no such strictures, and the form, enabled by the glowing endorsements of prominent literary women, attracted countless scores of women writers, some of whom used hymn forms in private religious writings and others whose compositions would be set to music and printed for public circulation. Though compositions by women hymnists always remained a minority of hymns in circulation, some of the best known, most beloved hymnists of the century were women writers, among them Sarah Flower Adams, Cecil Frances Alexander, Fanny Crosby, Charlotte Elliott, Frances Ridley Havergal, and Felicia Hemans. And as a key indicator of the vitality of hymnody both 
as a gendered genre and as a sentimental genre in particular, many of the major women writers of the mid-century-such as Lydia Sigourney, Harriet Beecher Stowe, and Susan Warnerenjoyed renown not only for their novels but also for their numerous hymns, which were set to music, included in hymnals and hymnbooks, and sung by congregations. Until their recent rediscovery by scholars of women's literature, Alice and Phoebe Cary were best remembered as the authors of such hymns as "Nearer Home" and "Dying Hymn." ${ }_{44}$ Popular women writers celebrated in their own time but overlooked by literary history were also important contributors to the hymn form, such as Elizabeth Prentiss, author of the best-selling novel Stepping Heavenward (I869) as well as numerous novels for younger readers; she wrote many hymns during her lifetime, and her hymn "More Love to Thee, O Christ" remains in circulation today among numerous Protestant denominations. Likewise, Anna Warner, sister of Susan Warner, composed numerous successful hymns, among them the internationally famous children's hymn "Jesus Loves Me." Julia Ward Howe is best remembered for her "Battle Hymn of the Republic," and Margaret Fuller is credited with the hymn "Jesus, a Child his Course Begun." Some of these women sought to curate hymns themselves: for example, Anna Warner edited several collections, such as Hymns of the Church Militant (I858) and Wayfaring Hymns (I869), and Phoebe Cary co-edited the I869 collection Hymnsfor all Christians with her pastor, Rev. Charles Deems.

Just as their novels portrayed hymnody as fully congruent with pious femininity, so their hymns are discernibly informed by this same cultural ethos, visibly referencing such sentimental hallmarks as modesty, authenticity, private domesticity, and aspiration for self-betterment. ${ }^{65}$ In effect, their hymns bridged the gap between these two female-gendered genres and infused a long-peripheral genre with the qualities and beliefs that gave sentimentalism such profound cultural purchase. The end results were mutually beneficial: sentimental discourse imparted respectability to this suspect genre, and hymns enabled sentimentalism to acquire genuine religious authority. Stowe's hymns are an illustrative case in point. Of the writers in her cohort, none had a stronger imprimatur to contribute to 
hymnody than did she. As daughter, sister, and wife of clergy, Stowe had impeccable religious pedigree, and the sensation that was Uncle Tom's Cabin positioned her as a significant evangelical voice. Her contributions to hymnody began at the hands of her brothers Henry and Charles, who set three of her poems to music composed by Charles in the Plymouth Collection (I855), the hymnbook born out of the famous singing at Henry's Brooklyn congregation. Her oft-reprinted hymns were revered equally for their religious sentiment and literary caliber. As was typical of the form, the personal experiences behind some of Stowe's hymns would garner attention, as with her hymn "The Secret," which was erroneously reputed to derive from her grief following her son's brain injury at Gettysburg, despite the fact that it was first published nearly a decade earlier. ${ }^{66}$

Stowe's "Still, Still with Thee" was perhaps her most popular hymn, appearing in at least ten different hymn collections by the end of the century. ${ }^{67}$ Hymnologist E. E. Ryden has claimed that "for sheer poetic beauty there is probably not a single American lyric that can excel 'Still, Still with Thee." 68 The hymn visibly incorporates many of the same generic standards that permeate fictional depictions as well as more genteel female-authored hymns. Like Phoebe Brown's "Twilight Ramble," the hymn was reputed to have originated in Stowe's own solitary walks: Edward Ninde claimed that in I853 Stowe shared the hymn's lyrics with a companion during an early morning stroll and described them as "verses which she had written at such an hour." ${ }^{69}$ As a consequence the hymn was cloaked in the mantle of biographical authenticity, a presumption that invites the hymn to be received not as a literary composition crafted with professional expertise but as a homely, modest expression of personal faith, born out of private experience and feeling rather than the expectation of the public eye. The hymn's contents fortified this autobiographical reading, for the hymn itself describes the prayerful pursuit of divine communion during an early morning walk, "[w] hen the bird waketh and the shadows flee." Over the course of six stanzas, the hymn repeatedly affirms its subscription to polite standards of class, taste, and respectability. For example, it extols the devotional merits of quiet repose and solitude, as the speaker regards the 
early morning as a special occasion to feel "nearness to Thee and heaven." Whereas revival or camp meeting hymns often invited singers to shout or publicly proclaim God's praises, as with Fanny Crosby's lyric assertion that "the children of the Lord have a right to shout and sing," Stowe's hymn instead celebrates the spiritual rewards of private, silent reflection. ${ }^{70}$ The fifth stanza, for instance, describes the virtues of praying silently while abed at night, for such practices, she suggests, afford rest and relief from life's burdens: "When sinks the soul, subdued by toil, to slumber / Its closing eye looks up to Thee in prayer, / Sweet the repose beneath Thy wings o'ershading." And just as mid-century novels depict hymnody as a vehicle for self-improvement and refinement, so does Stowe's hymn interpret daybreak as a reminder that every day provides another opportunity for spiritual rejuvenation and betterment: she writes, "as to each new-born morning / A fresh and solemn splendor still is given, / So does this blessed consciousness awaking." In the logic of the hymn, this pursuit of self-improvement is implicitly associated with the development of a finer, more attentive aesthetic sensibility, as the speaker's growing spiritual reverence is both activated and signaled by a keen appreciation for beauty. In its delight in the "purple morning" and the "calm dew and freshness of the morn," the hymn presumes that, in engendering mindfulness and gratitude, faith enables the detection of beauty in the commonplace. In heightening aesthetic receptivity in this fashion, piety cultivates the sensibilities and thereby implicitly furthers the refinement of the faithful. ${ }^{71}$

Alcott's hymn "My Kingdom" acquired renown because it similarly broadcast its fidelity to the normative pious femininity that coursed through much of Alcott's fiction. Though Under the Lilacs is remembered merely as a minor work in Alcott's corpus, "My Kingdom" became a beloved and successful hymn, set to several different musical arrangements and included in both hymnbooks and children's poetry collections well into the twentieth century. Alcott promoted "My Kingdom" by publicly emphasizing its origins in personal experience and private reflection. Alcott began to circulate the poem several years before the I877 publication of Under the Lilacs, when such works-hymns written by amateur women in moments of private reflection- 
had already developed particular currency. Eva Munson Smith, herself an amateur composer and philanthropist, contacted Alcott in research for her mammoth work, Woman in Sacred Song: A Library of Hymns, Religious Poems, and Sacred Music by Woman (I888), a comprehensive anthology that suggests that, by the late century, women were recognized and even celebrated as hymnists of high caliber. Alcott responded by submitting "My Kingdom," which she described in her 1875 cover letter as "the only hymn I ever wrote. It was composed at thirteen, and as I still find the same difficulty in governing my kingdom, it still expresses my soul's desire, and I have nothing better to offer." ${ }^{72}$ In this description, Alcott bolsters the hymn with public professions of modesty and imperfection: by undercutting her public stature and openly admitting her shortcomings, Alcott trumpets the hymn's authenticity and emotional sincerity. Though the publication of Smith's volume was delayed for over a decade, "My Kingdom" was published that same year, I875, in the children's collection The Sunny Side, edited by Unitarian minister Charles W. Wendté and H.S. Perkins. Alcott submitted "My Kingdom" with a note that identified the poem as a product of her own youth: "I send you a little piece which I found in an old journal, kept when I was about thirteen years old. . . Coming from a child's heart, when conscious of its wants and weaknesses, it may go to the hearts of other children in like mood."73 Lest her readers interpret the poem's child-like voice as imitative pandering, Alcott here clarifies that the hymn had been composed during her own youthful private reflections, in a scenario very much like that of contemporary fiction depicting the uses of hymns for struggling young people. Wendté and Perkins were clearly aware that they were in possession of something special, and they identified the hymn as an "original poetic contribution" on their title page, and reprinted this personal explanation as the head note to the poem itself, taking care to identify this narrative as coming from "a private letter" (italics in original) to emphasize its humble derivation from a private moment of trial and, by extension, its authenticity. Alcott further burnished the hymn's modest origins by attributing it, two years later in Under the Lilacs, to Miss Gelia, who makes a similar confession to youthful authorship: she tells Ben, "I feel very proud to think 
you chose that [hymn], and to hear you say it as if it meant something to you. I was only fourteen when I wrote it; but it came right out of my heart, and did me good. I hope it may help you a little." "74

Similar beliefs suffuse the hymns of Anna Warner, a wellregarded evangelical author of many novels as well as jointlywritten works with her sister, Susan. Her fiction is seldom remembered today, even by specialists in nineteenth-century women's literature, but many of her hymns endure. In her memoir of her sister, Susan Warner (I909), Anna reprinted a lengthy passage from Susan's diary to describe the beginnings of her career as a hymnist. Susan wrote,

The next day, Sunday, in the afternoon, A. [her short-hand for Anna] had been copying off some hymns ... and left them with me to look over. I had not read two verses of 'We Would See Jesus,' when I thought of Anna, and merely casting my eye down [sic] the others so delighted and touched me that I left it for tears and petitions. I wished A. might prove the author-and after found out she was, I sat by her a little while with my head against her crying such delicious tears. It seemed to me as if other people find pleasure on the earth, and as if A. and I go skimming through the air to get it,--more refined and pure. Thank God for this. ${ }^{75}$

Though Anna at the time of the memoir's publication had already acquired international acclaim for her children's hymn "Jesus Loves Me," this excerpt depicts her as a retiring, amateur female hymnist whose verses derive from private heart-felt yearnings and piety rather than slick careerism. Notably, Susan's final remarks in this diary entry candidly state her belief that feminine piety and private religious reflection are innately more "refined and pure" than worldly ambition or pleasure, beliefs that plainly underlie her portrayal of hymnody in The Wide, Wide World. In publishing this entry, Anna suggests as well that the hymn "We Would See Jesus" would have remained 


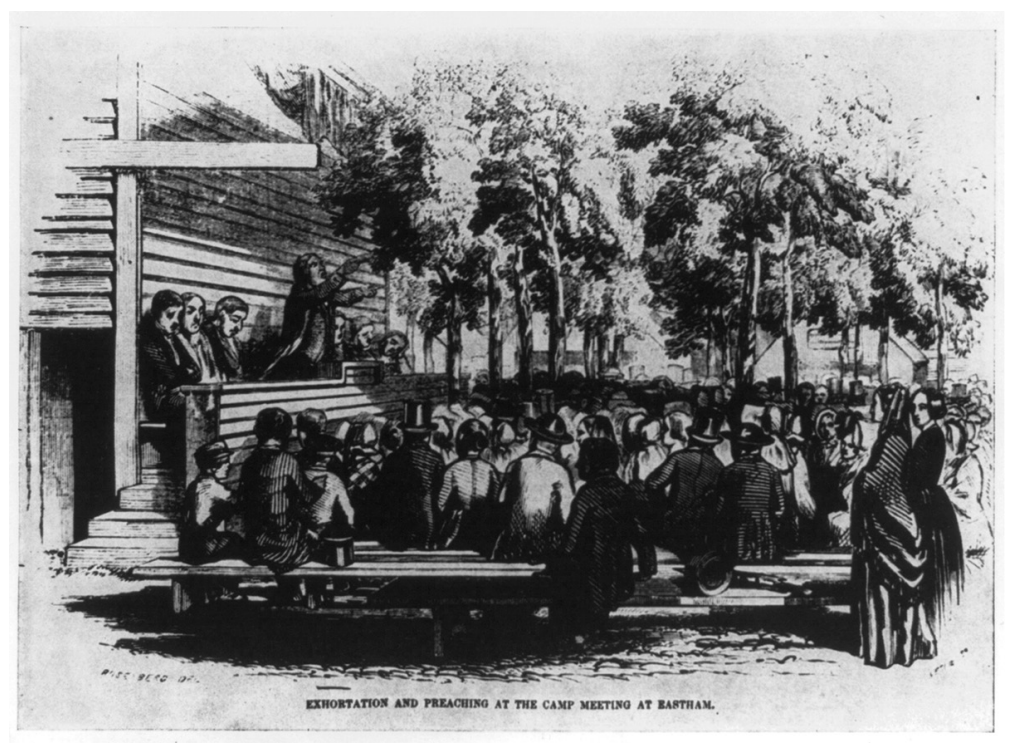

Religious Revival Meeting at Eastham, Mass., 1852: Exhortation and Preaching. Courtesy of Library of Congress, Pictures and Photographs Division. LC-USZ62-70638. 
private had it not received the benison of her famous sister, and Anna would make the hymn public, albeit as discreetly as possible, by including it in her novel Dollars and Cents (I852). As was typical of nineteenth-century women writers looking to preserve their modesty and respectability, she published the novel pseudonymously under the name Amy Lathrop, and she inserted the hymn in the novel without any attribution of authorship or invitation of acclaim. ${ }^{76}$ In the novel, two sisters, Katy and Grace, sing hymns to their beloved friend Miss Easy on her death bed; she requests that they sing her "favourite" hymn, and they comply with the words of Anna's own hymn "We Would See Jesus" about the yearnings for intimacy with Christ amid worldly travails. ${ }^{77}$ The elision of Anna's own authorship emerges as a supreme gesture of modesty and self-control, subordinating her ego and ambition out of an apparent desire to proffer a hymn that may provide comfort to those in need during times of trouble. In this respect, she models the self-effacement, privacy, and unassuming restraint that her female contemporaries upheld as the chief consequences of hymnody and of sentimentalism more generally. "Jesus Loves Me" was published under similar circumstances. In the I860 novel Say and Seal, coauthored by both Warner sisters, the main character, Faith Derrick, observes the seminarian John Linden sing a simple children's hymn to a dying orphan boy. As with "We Would See Jesus," she included the hymn with no introduction and with no clear attribution of authorship. Though both hymns would circulate widely and be included in denominational hymnals designed for public congregational worship, both novels present the hymns in the most intimate and withdrawn of domestic spaces, at the bedsides of the dying. As an extension of this enclosure of hymns in private physical spaces, Anna suggests that hymns are invaluable resources for trials of the most solitary kind, as the dying prepare to face the unknown in the afterlife and seek assurances that they will meet their maker. That is, though these hymns are sung to the dying by well-meaning caregivers, they gain purchase in the private interiority of those undergoing the most introverted and personal of experiences. Through these novelistic introductions, Anna Warner shrouded her hymns, as it were, in privacy, 
solitude, and modesty, all of which affirm her own feminine respectability and her qualification to write such works.

The modesty and humility of "Jesus Loves Me" are inversely proportional to the extraordinary international renown that the hymn would achieve, and this suggestive ratio may elucidate the larger function of these generic registers. To be sure, these affirmations of privacy, humility, and inadequacy helped craft an image of hymnody that neutralized the form's very publicity and egalitarian origins, moderating the hymn's capacity to upset social norms with assurances and displays of feminine traditionalism. These assurances of privacy and domesticity also seem to have provided the necessary ballast that enabled the hymn eventually to find inclusion in public worship, serving as a counterweight that ensured that public performance would never devolve into an unseemly spectacle like that of the revival meeting. At the same time, these declarations of conservatism enabled these women to work in a form that, for the first time, gave them a genuine voice in American Christianity and allowed them to create and shape religious views and experience. ${ }^{78}$ Though today hymns are no longer touted for their importance, there is no discounting the potency and power afforded by hymnody in the nineteenth century. Hymns were not simply poems set to music, but were interpreted as theological works in their own right, refined in the crucible of personal experience to transmit essential religious doctrine about the nature of divinity, human beings, and faith, as well as the responsibilities of the believing Christian. According to Henry Ward Beecher, "hymns are worship, and should be respected as such." 79 In recounting beliefs presumably learned from trial or offering thanks or praise, hymns modeled behaviors as well as ways of engaging with divinity, and, in the opinion of nineteenthcentury observers and evangelists, the influence of hymns on believers and infidels alike was substantial. Hymns were widely credited with inciting conversion and moral reform, and they were upheld as important foundations of childhood education and character building. ${ }^{80}$ Children were urged to memorize hymns out of the belief that religious verses learned in youth could exert moral influence throughout life.$^{8 \mathrm{I}}$ In the mindset of the nineteenth century, hymns had the power to shape or 
change a person's life, sending them on the road to righteousness and salvation. The religious impact and theological content of hymnody is at the fore of Beecher's remark that, "with a Bible and a hymn-book a man has a whole library; and if he knows how to use those two things, he knows enough to be a missionary, or to be a minister anywhere." 82 Though literary women may have endorsed conventional notions of propriety, it is no mean or humble thing to elect to work in a form with such transformational power and authority. The hymn enabled sentimentalism to acquire a genuine foothold in formal religious ritual and literary women to become legitimate religious authorities. These public professions of modesty perhaps served as a cover for the continuation, however clandestine, of the subversive tradition of hymnody.

Trinity University

NOTES

I wish to thank Mary De Jong, Deborah Rhine, and Claudia Scholz for their invaluable help with this essay. The writing of the essay was supported by a summer stipend provided by the National Endowment for the Humanities.

I. Samuel J. Rogal, A General Introduction to Hymnody and Congregational Song (Metuchen, NJ: Scarecrow Press, I99I), 22-23.

2. Margaret Maison, "'Thine, Only Thine!' Women Hymn Writers in Britain, I760-1835," Religion in the Lives of English Women, 1760-1930, ed. Gail Malmgreen (Bloomington: Indiana Univ. Press, I986), I2.

3. John Wesley, "Directions for Singing," in A Collection of Hymns for the Use of the People Called Methodists, ed. Franz Hildebrandt and Oliver A. Beckerlegge, vol. 7 of The Works of John Wesley (Oxford: Clarendon, I983), 765.

4. The Bay Psalm Book, Being a Facsimile Reprint of the First Edition, Printed by Stephen Daye, at Cambridge in New England, 1640 (New York: Dodd, Mead, I905), xviii, np.

5. Gareth Lloyd, Charles Wesley and the Struggle for Methodist Identity (New York: Oxford, 2007), 73, 74.

6. Isaac Watts, Preface to Hymns and Spiritual Songs (London: Strahan and Rivington, I773), iii, iv.

7. Watts, Preface to Hymns and Spiritual Songs, vii-viii. 
8. Isaac Watts, Divine and Moral Songs for Children (New York: Hurd and Houghton, I866), 9.

9. Watts, Preface to Hymns and Spiritual Songs, viii-ix.

IO. For a fuller history of this phenomenon, see Nancy A. Hardesty, Women Called to Witness: Evangelical Feminism in the 19th Century (Nashville: Abingdon, 1984) and Catherine A. Brekus, Strangers \& Pilgrims: Female Preaching in America, 1740-1845 (Chapel Hill: Univ. of North Carolina Press, 1998).

II. Ann Taves, Fits, Trances, \& Visions: Experiencing Religion and Explaining Experience from Wesley to James (Princeton: Princeton Univ. Press, I999), 76-II7.

I2. Mark A. Noll corroborates this argument in his work America's God: From Jonathan Edwards to Abraham Lincoln (New York: Oxford Univ. Press, 2002), 336-37.

I3. Lloyd, Charles Wesley, 74; Franz Hildebrandt, "A Little Body of Experimental and Practical Divinity," introduction to A Collection of Hymns for the Use of the People Called Methodists, vol. 7 of The Works of John Wesley (Oxford: Clarendon Press, I983), 22.

I4. Quoted in Lloyd, Charles Wesley, 74.

I5. Lloyd, Charles Wesley, 75.

I6. Nathan O. Hatch, The Democratization of American Christianity (New Haven: Yale Univ. Press, I989), I5I-53.

I7. Louis F. Benson, The English Hymn: Its Development and Use in Worship (New York: Hodder \& Stoughton, I9I5), 359, 360; William J. Reynolds, A Survey of Christian Hymnody, 3rd ed. (Carol Stream, IL: Hope Publishers, I987), 87.

I8. Sandra S. Sizer, Gospel Hymns and Social Religion: The Rhetoric of NineteenthCentury Revivalism (Philadelphia: Temple Univ. Press, 1978), 66-67; Reynolds, Christian Hymnody, 92.

I9. William G. McLoughlin, Revivals, Awakenings, and Reform: An Essay on Religion and Social Change in American, 1607-1977 (Chicago: Univ. of Chicago Press, I978), II.

20. In I830, both the Presbyterians and Congregationalists issued hymnals, and the Baptists followed in I843. Susan VanZanten Gallagher, "Domesticity in American Hymns, I820-I870," Sing Them Over Again to Me: Hymns and Hymnbooks in America, ed. Mark A. Noll and Edith L. Blumhofer (Tuscaloosa: Univ. of Alabama Press, 2006), 239-40.

2I. Mary De Jong, "'Theirs the Sweetest Songs': Women Hymn Writers in the Nineteenth-Century Unites States," A Mighty Baptism: Race, Gender, and the Creation of American Protestantism, ed. Susan Juster and Lisa MacFarlane (Ithaca: Cornell Univ. Press, I996), I49. 
22. Henry Wilder Foote, Three Centuries of American Hymnody (Cambridge: Harvard Univ. Press, I940), 203.

23. Benson, English Hymn, 375-76.

24. Gallagher, "Domesticity," 240.

25. Asahel Nettleton, Preface to Village Hymnsfor Social Worship, Selected and Original, 2d. ed. (New York: Goodwin, I824), v-vi. In the latter portion of these remarks, Nettleton quotes from, and agrees with, an unattributed letter from a "much respected correspondent" (vi).

26. Stephen Marini, "From Classical to Modern: Hymnody and the Development of American Evangelicalism, I737-1970," in Singing the Lord's Song in a Strange Land: Hymnody in the History of North American Protestantism, ed. Edith L. Blumhofer and Mark A. Noll (Tuscaloosa: Univ. of Alabama, 2004), I.

27. Leonard Ellinwood, "Religious Music in America," Religious Perspectives in American Culture, ed. James Ward Smith and A. Leland Jamison (Princeton: Princeton Univ. Press, I96I), 2:327.

28. Mary De Jong, "'I Want to be like Jesus': The Self-Defining Power of Evangelical Hymnody," Journal of the American Academy of Religion 54, no. 3 (I986): 46I.

29. Mary De Jong, "Textual Editing and the 'Making' of Hymns in Nineteenth-Century America," Sing Them Over to Me Again: Hymns and Hymnbooks in America, ed. Mark A. Noll and Edith L. Blumhofer (Tuscaloosa: Univ. of Alabama Press, 2006), 77.

30. Candy Gunther Brown, The Word in the World: Evangelical Writing, Publishing, and Reading in America, 1789-1880 (Chapel Hill: Univ. of North Carolina Press, 2004), I99; De Jong, "Sweetest," I42.

31. Henry Ward Beecher, introduction to Plymouth Collection of Hymns and Tunes; For the Use of Christian Congregations (New York: A. S. Barnes, I855), vii.

32. Susan Warner, The Wide, Wide World (New York: Feminist Press, 1987), $24 \mathrm{I}$.

33. Warner, The Wide, Wide World, 545 .

34. Marianne Noble analyzed the ways in which sentimental fiction presents invisibility as a hallmark of feminine piety. Marianne Noble, The Masochistic Pleasures of Sentimental Literature (Princeton: Princeton Univ. Press, 2000), 33.

35. Numerous commentators have glossed these marked tendencies of the American middle class. See, for instance, Joan Shelley Rubin, The Making of Middlebrow Culture (Chapel Hill: Univ. of North Carolina Press, 1992), 4-5; Ronald J. Zboray, A Fictive People: Antebellum Economic Development and 
the American Reading Public (New York: Oxford Univ. Press, 1993), 84; Thomas Augst, The Clerk's Tale: Young Men and Moral Life in Nineteenth-Century America (Chicago: Univ. of Chicago Press, 2003), I77-9I.

36. For a more extensive discussion of the centrality of self-control in sentimental narrative, see Jane Tompkins, Sensational Designs: The Cultural Work of American Fiction 1790-1860 (New York: Oxford Univ. Press, I985), I65ff.

37. Harriet Beecher Stowe, Agnes of Sorrento (Boston: Ticknor and Fields, I862), 247, I5I.

38. Harriet Beecher Stowe, Oldtown Folks (New Brunswick: Rutgers Univ. Press, 1987), 331).

39. Harriet Beecher Stowe, "The First Christmas of New England," in Betty's Bright Idea (New York: J. B. Ford, I876), 93.

40. Lyman Beecher's involvement in the changing attitudes and practices of devotional music are described in an anecdote by important hymnist Lowell Mason in The Autobiography, Correspondence, \&c. of Lyman Beecher, ed. Charles Beecher (London: Sampson Low, Son and Marsden, I863), 2:I50-5I.

4I. Harriet Beecher Stowe, Uncle Tom's Cabin or, Life among the Lowly, ed. Ann Douglas (New York: Penguin, I98I), 44.

42. Stowe, Uncle Tom's Cabin, 77, 78.

43. Nina Baym has analyzed the ways in which sentimentalism generally advocates this perception of suffering as temporary trials diminished by the awareness of a broader spiritual context. Nina Baym, Woman's Fiction: A Guide to Novels by and about Women in America, 1820-1870, 2d ed. (Urbana: Univ. of Illinois Press, I993), 42.

44. Stowe, Uncle Tom's Cabin, 554, 555. According to Jonathan Aitken, Stowe made some editorial changes to these verses, switching the first lines of the first two stanzas. In addition, Stowe contributes a new final verse to the hymn and inserts a line from the hymn "Jerusalem, My Happy Home" as well as elements from revival hymnody. Jonathan Aitken, John Newton: From Disgrace to Amazing Grace (Wheaton: Crossways, 2007), 235

45. Stowe, Uncle Tom's Cabin, 77.

46. Harriet Beecher Stowe, Dred: A Dismal Tale of the Great Swamp (I856; reprint, Gross Pointe: Scholarly Press, I968), 2:I5, I6, I7.

47. Louisa May Alcott, Under the Lilacs (Boston: Little, Brown, I928), III-I2.

48. Gillian Brown has observed that this dynamic is evident in numerous works of sentimental women's literature. Gillian Brown, Domestic Individualism: Imagining Self in Nineteenth-Century America (Berkeley: Univ. of California Press, I990), 3. 
49. June Hadden Hobbs has examined the female-orientation of U.S. hymns, albeit in works composed decades later and by hymnists, such as Fanny Crosby, associated chiefly with revival or gospel hymns. By contrast, this essay seeks to show that this gender orientation occurs considerably earlier and in a genre marked by its displays of refinement. See June Hadden Hobbs, "I Sing for I Cannot be Silent": The Feminization of American Hymnody, 1870-1920 (Pittsburgh: Univ. of Pittsburgh Press, I997).

50. Hobbs, "I Sing," 68-69.

51. De Jong, "Sweetest," I54-55; Samuel J. Rogal, Sisters of Sacred Song: A Selected Listing of Women Hymnodists in Great Britain and America (New York: Garland, I98I), xi-xii.

52. De Jong, "Sweetest,' I43; Elizabeth F. Gray, "Beatification through Beautification: Poetry in The Christian Lady's Magazine, I834-I849," Victorian Poetry 42, no. 3 (2004): 262.

53. Gray, "Beatification," 267.

54. She wrote that the Magnificat shows "evidence of a soul not only exalted by genius and enthusiasm, but steeped in the traditions of ancient prophesy. It is so like the Psalms of David that a verse of it, if read casually, might seem to be taken from them." Harriet Beecher Stowe, Footsteps of the Master (New York: J.B. Ford, I877), 7I.

55. In this regard, the hymn complies with what Lauren Berlant has termed "women's intimate public": a public presentation that presents itself as confidential and private. Lauren Berlant, The Female Complaint: The Unfinished Business of Sentimentality in American Culture (Durham: Duke Univ. Press, 2008), 27.

56. De Jong, "Sweetest," I64.

57. June Howard has analyzed more extensively the conflicted insistence on emotional authenticity in sentimental literature. June Howard, "What is Sentimentality?” American Literary History II (I999): 65-66.

58. Quoted in George Prentiss, The Life and Letters of Elizabeth Prentiss (New York: Anson D. F. Randolph, I882), 422.

59. Fanny J. Grosby, Memories of Eighty Years (Boston: James H. Earle, I906), I66-67.

60. Nancy Cott estimates that women outnumbered men by a third in these settings, though Richard Brown contends that women outnumbered men at times by a ratio of three to one. Nancy F. Cott, "Young Women in the Second Great Awakening," Feminist Studies , no. I-2 (I975): I5-I6; Nancy F. Cott, The Bonds of Womanhood: "Woman's Sphere" in New England, 1780- 
1835 (New Haven: Yale Univ. Press, 1977), I27; Richard D. Brown, Knowledge is Power: The Diffusion of Information in Early America, 1700-1865 (New York: Oxford Univ. Press, I989), I62; Brekus, Strangers \& Pilgrims, I24.

6I. Sources differ on the original title of Brown's poem. Some sources, such as Mary De Jong and Edward Ninde, term the poem "My Apology for my Twilight Rambles, Address to a Lady," while others omit the possessive pronounce "My" altogether.

62. Nettleton would remove all references to personal content and replace them with more broadly inclusive lines. For example, he removed the gender-specific line "From little ones and care" and replaced it with "From every cumbering care." De Jong, "Sweetest," I50; E. E. Ryden, The Story of Christian Hymnody (Rock Island, IL: Augustana Press, I96I), 472.

63. Nicholas Smith, Songs from the Hearts of Women: One Hundred Famous Hymns and Their Writers (Chicago: A.C. McClurg, I903), 37; Edward S. Ninde, The Story of the American Hymn (New York: Abingdon, I92I), I78-79, I8I.

64. In her memoir of the Cary sisters, Mary Clemmer Ames writes, "No singer was ever more thoroughly identified with her own songs than Phoebe Cary. With but few exceptions, they distilled the deepest and sweetest music of her soul.” Mary Clemmer Ames, A Memorial of Alice and Phoebe Cary, with Some of their Later Poems (New York: Hurd and Houghton, I873), I55.

65. Mary Kelley has argued that this entanglement of private and public personae is characteristic of sentimental literature more generally. Mary Kelley, Private Woman, Public Stage: Literary Domesticity in Nineteenth-Century America (New York: Oxford Univ. Press, I984).

66. Ninde, American Hymn, 248-49.

67. De Jong, "Sweetest," I56.

68. Ryden, Christian Hymnody, 521.

69. Robert J. Morgan, Then Sings My Soul: 150 of the World's Greatest Hymns Stories (Nashville: Thomas Nelson, Inc., 2003) I29; Ninde, American Hymn, 245 .

70. Qtd. in W. McDonald, Joshua Gill et al., Songs ofJoy and Gladness (Boston: McDonald, Gill, I888), 74.

7I. Harriet Beecher Stowe, "Still, Still with Thee," Plymouth Collection of Hymn and Tunes (New York: A.S. Barnes, I858), 2 I4.

72. Qtd. in Eva Munson Smith, Woman in Sacred Song: A Library of Hymns, Religious Poems, and Sacred Music by Woman (Oakland: Arthur E. Whitney, I888), 668.

73. Quoted in Charles W. Wendté and H. S. Perkins, The Sunny Side: A Book 
of Religious Songs for the Sunday School and the Home (New York: William A. Pond, I875), 45. Charles Hughes confuses Alcott's explanations for "My Kingdom" and attributes this preface in the Sunny Side to a letter to Eva Smith. Gharles Hughes, American Hymns Old and New: Notes on the Hymns and Biographies of the Authors and Composers (New York: Columbia Univ. Press, 1980), I36-37.

74. Alcott, Under the Lilacs, II4. Critics would pursue Alcott's autobiographical claim by attempting to generate the requisite background story attesting to the hymn's creation and worth. Such a story has proved elusive, but would begin the year following Alcott's death with the publication of Alcott's post-mortem Life, Letters and Journals (I889), edited by Ednah Cheney, a New England writer and reformer who wrote the occasional hymn. In that work she reprinted Alcott's journal entry from August I850, where, at the age of eighteen, in confessing to feelings of disorderliness, she recalled a poem she'd written years before: "I'm not a good housekeeper, and never get my room in nice order. I once wrote a poem about it when I was fourteen, and called it 'My Little Kingdom.' It is still hard to rule it, and always will be I think" [Quoted in Ednah D. Gheney, Louisa May Alcott: Her Life, Letters, and Journals (I889; reprint, New York: Chelsea House, I980), 59]. Cheney reproduced the poem in its entirety as an epigraph to her chapter on Alcott's experience at Fruitlands, her father's famously unsuccessful attempt at a Utopian commune, and subsequent critics, such as Karen Haltunnen, have taken that placement as confirmation that Alcott wrote "My Kingdom" while at Fruitlands, though she was only ten years old at the time and though she claims to have written it in early adolescence at age thirteen or fourteen. Regardless, no definitive story has ever emerged. Karen Halttunen, "The Domestic Drama of Louisa May Alcott," Feminist Studies IO, no. 2 (I984): 237

75. Quoted in Anna Warner, Susan Warner (New York: Putnam, I90I), $342-43$.

76. For elaboration on the use of self-erasure in nineteenth-century women's poetry, see Paula Bernat Bennett, Poets in the Public Sphere: The Emancipatory Project of American Women's Poetry, 1800-1900 (Princeton: Princeton Univ. Press, 2003), 25-27.

77. Amy Lothrop, Glen Luna; or, Dollars and Cents (London: James Nisbet, I870), 253. This edition was published using Warner's pseudonym and one of the novel's numerous alternate titles. 
78. In this regard, the history of nineteenth-century hymnody echoes Jane Tompkins oft-cited observation that mid-century women writers advocated submission and decorum as an indirect means of achieving authority. Tompkins, Sensational, I63.

79. Henry Ward Beecher, "Relations of Music to Worship," Yale Lectures on Preaching (New York: Fords, Howard, and Hurlbert, I896), 2:129.

80. Brown, Word in the World, I9I-92; De Jong, "Sweetest," I4I-42.

8I. Brown, Word in the World, 200.

82. Beecher, "Music," I37. 